\title{
Effect of Cellulolytic Pretreatment of Agricultural Waste on Organic Matter Degradation
}

\author{
B. Prasanna Kumar*, S. Triveni, R. Subhash Reddy and A. Vijaya Gopal \\ Department of Agricultural Microbiology and Bioenergy, College of Agriculture, \\ Rajendranagar, Hyderabad, India \\ *Corresponding author
}

Keywords

Cellulose,

Cellulomonas,

Bacillus,

Pseudomonas,

Penicillium,

Aspergillus,

Maize straw.

Article Info

Accepted:

08 November 2016

Available Online:

10 December 2016

\section{A B S T R A C T}

A Maize straw - cellulose degrading microbes were isolated from different soil samples and also from waste samples. The efficient cellulose degrading microorganisms was identified as Cellulomonas, Bacillus, Pseudomonas, Penicillium and Aspergillus. These cellulose degrading microorganisms were also tested for their cellulose degrading ability by quantitatively and qualitatively. The outstanding isolates were used for the pretreatment of agricultural waste (maize straw). The method of this biological pretreatment resulted the highest conversion of cellulose in maize straw to sugar and consequently, organic carbon degradation after some days of maize straw fermentation with cellulose degrading microorganisms.

\section{Introduction}

Cellulose is biologically renewable resource abundantly found in agriculture waste. Thecellulosic waste material can be hydrolysed to glucose and other soluble sugars by using cellulase enzymes of bacteria and fungi. The reducing sugars obtained can be further used for the production of ethanol as biofuel (Acharya $e t$ al., 2012). The potential cellulose producing bacteria are Cellulomonas, Pseudomonas, Thermoactinomycetes and Bacillus spp. (Godana, 2007). Sustainable resources, which are in need of human being, are derived from plant biomass. Cellulose is the major component of plant biomass
(Camassola and Dillon, 2007). Cellulolysis is basically the biological process controlled and processed by the enzymes of cellulase system. Cellulase enzyme system comprises three classes of soluble extracellular enzymes: 1 , 4- $\beta$-endoglucanase, $1,4-\beta$ exoglucanase, and $\beta$-glucosidase ( $\beta$-Dglucoside glucohydrolase or cellobiase). Endoglucanase is responsible for random cleavage of $\beta-1,4-$ glycosidic bonds along a cellulose chain. Exoglucanase is necessary for cleavage of the non-reducing end of a cellulose chain and splitting of the elementary fibrils from the crystalline cellulose, and $\beta$-1, 4-glucosidase hydrolyses 
cellobiose and water-soluble cellodextrin to glucose (Shewale, 1982), (Woodward and Wiseman, 1983). Only the synergy of the above three enzymes makes the complete cellulose hydrolysis to glucose (Ryu and Mandels, 1982; Wood, 1989) or a thorough mineralization to $\mathrm{H}_{2} \mathrm{O}$ and $\mathrm{CO}_{2}$ possible.

Many microorganisms are capable of degrading and utilizing cellulose and hemicellulose as carbon and energy sources. During composting, the capacity of thermophilic microorganisms to assimilate organic matter depends on their ability to produce the enzymes needed for degradation of the substrate. Both fungi and bacteria have been heavily exploited for their abilities to produce a wide variety of cellulases and hemicellulases. Most emphasis has been placed on the use of fungi because of their capability to produce copious amounts of cellulases and hemicellulases which are secreted into the medium for easy extraction and purification. In addition, the enzymes are often less complex than bacterial glycoside hydrolases and can therefore be more readily cloned and produced via recombination in a rapidly growing bacterial host such as Escherichia coli. However, the isolation and characterization of novel glycoside hydrolases from Eubacteria are now being widely exploited. There are several reasons for these shifts, for one, bacteria often have a higher growth rate than fungi allowing for higher recombinant production of enzymes. Secondly, bacterial glycoside hydrolases are often more complex and are often expressed in multienzyme complexes providing increased function and synergy. The present study was focused on biodegradation of cellulosic waste materials viz., paddy straw, sugarcane bagasse and banana stalks using the cellulolytic fungi isolates, Trichoderma viride, Aspergillus niger and Fusarium oxysporum.

\section{Materials and Methods}

Isolation of cellulolytic bacteria cellulolytic bacterial strains were isolated from soil by usingserial dilutions and pour plate technique. The medium used for isolation of cellulolytic bacteria contains $1.0 \%$ peptone, $1.0 \%$ carboxymethyl cellulose (CMC), $0.2 \%$ $\mathrm{K} 2 \mathrm{HPO} 4,1 \%$ agar, $0.03 \% \quad \mathrm{MgSO}_{4} .7 \mathrm{H}_{2} \mathrm{O}$, $0.25 \%\left(\mathrm{NH}_{4}\right)_{2} \mathrm{SO}_{4}$ and $0.2 \%$ gelatin at $\mathrm{pH} 7$ for 48 hours of incubation at $30^{\circ} \mathrm{C}$ (Yin et al., 2010). Bacterial colonies were purified by repeated streaking. The purified colonies were preserved at $4^{0} \mathrm{C}$ for further identification and screening for cellulase production.

\section{Screening of Cellulolytic Bacteria}

Pure cultures of bacterial isolates were individually transferred in CMC agar plates. After incubation for 48 hours, CMC agar plates were flooded with $1 \%$ congored and allowed to stand for $15 \mathrm{~min}$ at room temperature. One molar $\mathrm{NaCl}$ was thoroughly used for counterstaining the plates. Clear zones were appeared around growing bacterial colonies indicating cellulose hydrolysis (Andro et al., 1984). The bacterial colonies having the largest clear zone were selected for identification and cellulase production in submerged system.

\section{Identification of Cellulolytic Bacteria}

Identification of cellulolytic bacteria was carried out by method as described by Cowen and Steel (Cowan and Steel, 1993) and (Cullimore, 2000) which was based on morphological and biochemical tests.

\section{Inoculum development}

Pure cultures of selected bacterial isolates were individually maintained on CMC 
supplemented minimal agar slants at $4^{0} \mathrm{C}$, until used. Pure cultures of selected bacterial isolates were inoculated in broth medium containing $0.03 \% \mathrm{MgSO}_{4}, 0.2 \% \mathrm{~K}_{2} \mathrm{HPO}_{4}$, $1 \%$ glucose, $0.25 \%\left(\mathrm{NH}_{4}\right)_{2} \mathrm{SO}_{4}$ and $1 \%$ peptone at $\mathrm{pH} 7$ for $24 \mathrm{~h}$ of fermentation period. After $24 \mathrm{~h}$ of fermentation period these vegetative cells were used as inoculum source.

\section{Estimation of Cellulase activity}

Cellulase activity was assayed using dinitrosalicylic acid (DNS) reagent (Miller 1959)by estimation of reducing sugars released from CMC solubilized in $0.05 \mathrm{M}$ phosphate buffer at $\mathrm{pH} 8$ (Bailey et al., 1992). The culture broth was centrifuged at $14000 \times \mathrm{g}$ for $10 \mathrm{~min}$ at $4^{0} \mathrm{C}$ and the clear supernatant served as crude enzyme source. Crude enzyme was added to $0.5 \mathrm{ml}$ of $1 \%$ CMC in $0.05 \mathrm{M}$ phosphate buffer and incubated at $50^{\circ} \mathrm{C}$ for $30 \mathrm{~min}$. After incubation, reaction was stopped by the addition of $1.5 \mathrm{ml}$ of DNS reagent and boiled at $100^{\circ} \mathrm{C}$ in water bath for $10 \mathrm{~min}$. Sugars liberated were determined by measuring absorbance at $540 \mathrm{~nm}$. Cellulase production was estimated by using glucose calibration curve (Shoham et al., 1999). One unit (U) of enzyme activity is expressed as the quantity of enzyme, which is required to release $1 \mu \mathrm{mol}$ of glucose per minute under standard assay conditions

\section{Estimation of microbial population}

Total microbial biomass of compost samples was determined by serial dilution method. One gram of compost sample on dry weight basis was taken and serially diluted in sterile distilled water. One milliliter from each dilution was plated onto potato dextrose agar media and incubated at $30^{\circ} \mathrm{C}$ for $48 \mathrm{~h}$. The colony forming units (CFU) were counted and the values were multiplied with dilution factor and expressed in CFU/g of compost.

\section{Results and Discussion}

There are several important aspects that should be consideredfor the development of any bioprocess in solid state fermentation. These include selection of suitable microorganism and substrate, optimization of process parameters and separation of the product. In order to achieve high enzyme yield, efforts are made to develop a suitable medium and to work out the favourable environmental conditions for the proper growth and maximum secretion of enzyme. Development of such medium requires using the right selection of cheaper and readily available components.

\section{Soil sample collection}

Soil samples was collected from agricultural college student farm soil, farmer's agriculture field, forest soil and another sample was collected from horse dung FYM manure enriched soil sample nearby college. These soil samples were air dried and mixed thoroughly and sieved through a $2 \mathrm{~mm}$ sieve constituted the soil sample.

\section{Waste collection}

Samples were collected from waste receiving dustbin of Domestic kitchen wastes sample, Municipal solid waste sample, Sewage water sample and cow dung sample were collected in pre-sterilized screw cap glass vials of $30 \mathrm{ml}$ capacity were used.

\section{Isolation of Cellulose degrading Bacteria}

Cellulose degrading bacteria were isolated from different soil samples and waste samples by using CMC agar medium. Thirty morphologically distinct bacterial isolates which were giving halo zones in $\mathrm{CMC}$ agar medium were selected and named as $\mathrm{C}_{2} \mathrm{~A}$, $\mathrm{C}_{3} \mathrm{~A}, \mathrm{C}_{3} \mathrm{~B}, \mathrm{C}_{4} \mathrm{~A}, \mathrm{C}_{5} \mathrm{~A}$. Cellulose degrading 
bacteria were also isolated from Cow Dung Sample (CDS), Municipal Solid Waste (MSW), Domestic Kitchen Waste (DKW) and Sewage Water Sample (SWS). In the present study, number of cellulose degrading bacteria was observed from collected soil samples and waste samples (Table 4.1).

\section{Identification of the Isolates, Morphological Characterization, Colony Morphology, Gram's Staining}

The bacterial isolates were presumptively identified by means of morphological examination and biochemical characterisation. The parameters investigated included colony characteristics, shape, size, spore, motility, Gram's reaction (Table 4.1.1).

\section{Quantitative determination of cellulase activity of bacterial isolates}

The clearing zone size and colony diameter of these isolates were measured when incubated aerobically at $370 \mathrm{C}$; the result showed that maximum clearing zone ranged from 1.38 and $1.25 \mathrm{~cm}$ demonstrating that some of the isolates have the ability to degrade the carboxymethyl cellulose and indicating high ability of cellulase production. Distinct cellulase production was detected by bacterial isolate SWS-B as evidenced by its maximum clearing zone value of 1.37 (0.149 Unit/mg). This finding is very similar to the findings of Hatami et al. (2008) who also observed the ratio of the zone diameter to colony diameter ratio 0.4 to 2.1 (Table 4.2.1 and 4.2.2)

\section{Procedure for pretreatment}

First, $1 \mathrm{~g}$ dry ground corn straw powder was poured into a118 $\mathrm{ml}$ serum glass bottle, after which $10 \mathrm{ml}$ distilled water was added into the bottle. After autoclaving for $120 \mathrm{~min}$, the bottles were inoculated with the complex microbial agents in aseptic conditions. A
$0.01 \%(\mathrm{w} / \mathrm{w})$ dose of the complex microbial agents was used in our study. Each of 20 bottles was then covered and sealed with a plastic film. A sponge plug was inserted into the middle of the film to sparge air while preventing airborne microorganisms from entering the bottle. The control bottle was not inoculated with complex microbial agents. It only contained $1 \mathrm{~g}$ dry ground corn straw and $10 \mathrm{ml}$ distilled water. The bottles were placed in an incubation chamber. Samples were obtained on the $0^{\text {th }}$, $5^{\text {th }}, 10^{\text {th }}, 15^{\text {th }}$, and $20^{\text {th }}$ day of incubation for composition determination, chemical analyses, and biochemical methane potential (BMP) assay.

\section{Estimation of cellulose}

Cellulose content was estimated by the method of Uppdegraff (1969). Hundred milligram of pretreated of cellulosic wastes were added with $5 \mathrm{ml}$ of Nitric reagent and boiled and cooled. It was centrifuged at $5000 \mathrm{rpm}$ for $5 \mathrm{~min}$. The pellet was washed with distilled water. $10 \mathrm{ml}$ of 67 per cent sulphuric acid was added. $1 \mathrm{ml}$ of the sample was diluted to $100 \mathrm{ml}$. To $1 \mathrm{ml}$ of the each diluted solution, $10 \mathrm{ml}$ of freshly prepared ice cold anthrone reagent was added and boiled in a boiling water bath for $10 \mathrm{~min}$ at $100^{\circ} \mathrm{C}$. Absorbance was recorded at $600 \mathrm{~nm}$.

The numbers of microbes isolated and details of sample collection from the various locations are shown inTable 1 which indicate that the number of microbes were isolated from different soil samples and also from waste samples. Among these samples SWS sample has contain higher number of microbial population as compared to other samples. The isolated strains were also tested for their enzyme degradation efficiency by quantitative and qualitative methods. Among these strains SWS.10 ${ }^{-6}$. A strain has showing maximum zone of 
degradation and also maximum enzyme activity as 0.136 Unit/mg. Another strain four was also showing maximum zone of degradation and also maximum enzyme activity as $1.380 \quad$ Unit/mg. Initial composition of different parameters like $\mathrm{pH}$ of four treatments was more in $T_{3}$ (Vermicomposting without pretreatment) 8.25 and least recorded in $\mathrm{T}_{1}$ (Composting without pretreatment) 8.00 . The percentage of nitrogen content in the agricultural waste was more in $\mathrm{T}_{3}$ (Vermicomposting without pretreatment) 1.91 per cent and least recorded in $T_{1}$ (Composting without pretreatment) 0.60 per cent. The percentage of phosphorus content in the agricultural waste was more in $\mathrm{T}_{3}$ (Vermicomposting without pretreatment) and $\mathrm{T}_{4}$ (Vermicomposting with pretreatment) 1.00 per cent and least recorded in $T_{1}$ (Composting without pretreatment) 0.15 per cent. The percentage of potassium content in the agricultural waste was more in $T_{4}$ (Vermicomposting with pretreatment) 1.00 per cent and least recorded in $T_{1}$ (Composting without pretreatment) 0.65 per cent. The percentage of organic carbon content in the agricultural waste was more in $\mathrm{T}_{1}$ (Composting without pretreatment) 25.50 per cent and least recorded in $T_{3}$ (Vermicomposting without pretreatment) 21.60 per cent. The percentage of cellulose content in the agricultural waste was more in $\mathrm{T}_{2}$ (Composting with pretreatment) 27.58 per cent and least recorded in $T_{1}$ (Composting without pretreatment) 24.31 per cent (Table 4.4).

The above results were similar to that of Kumar et al., (2010) who studied on Composting of sugarcane waste by-products through treatment with microorganisms and subsequent vermicomposting and results were obtained as $\mathrm{N}$ content was $0.80,0.82$ and 0.85 . $\mathrm{P}$ content was $0.53,0.55$ and 0.58 per cent. K content was $1.28,1.60$ and 1.62 per cent respectively.
The above results were similar to that of Carey et al., (2016) who studied on Recovery of agricultural nutrients from biorefineries using combinations of physical, chemical, and biological operations will promote sustainability at biorefineries and results were obtained as $\mathrm{N}$ content was 1.30 per cent, $\mathrm{P}$ content was 0.21 per cent and $\mathrm{K}$ content was 1.48 per cent respectively.

At the time of pretreatment $\mathrm{pH}$ in the agricultural waste was more in $T_{4}$ (Vermicomposting with pretreatment) 8.28 and least in $\mathrm{T}_{1}$ (Composting without pretreatment) 8.18. $\mathrm{N}$ per cent in the agricultural waste was more in $T_{4}$ (Vermicomposting with pretreatment) 2.41 per cent and least in $\mathrm{T}_{1}$ (Composting without pretreatment) 0.70 per cent. $\mathrm{P}$ per cent in the agricultural waste was more in $T_{4}$ (Vermicomposting with pretreatment) 1.10 per cent and least in $\mathrm{T}_{1}$ (Composting without pretreatment) 0.17 per cent. $\mathrm{K}$ per cent in the agricultural waste was more in $T_{4}$ (Vermicomposting with pretreatment) 1.05 per cent and least in $\mathrm{T}_{1}$ (Composting without pretreatment) 0.72 per cent. Organic carbon per cent in the agricultural waste was more in $\mathrm{T}_{1}$ (Composting without pretreatment) 26.70 per cent and least in $T_{3}$ (Vermicomposting without pretreatment) 22.00 per cent. Cellulose per cent in the agricultural waste was more in $\mathrm{T}_{1}$ (Composting without pretreatment) 23.02 per cent and least in $\mathrm{T}_{4}$ (Vermicomposting with pretreatment) 21.10 per cent (Table $4.5)$.

The above results were similar to that of Lemee et al., (2012) who studied on Lignocellulosic biomass was submitted to a biological pretreatment prior to a catalytic hydroliquefaction in order to produce biofuel and results were obtained as $\mathrm{pH}$ in an aqueous suspension was 6.1, 7.4, 7.8 and 
8.2 and $\mathrm{N}$ per cent was $2.28,2.86,2.99$ and 3.14 respectively.

In the results of six treatments had more $\mathrm{N}$, $\mathrm{P}$ and $\mathrm{K}$ per cent in different intervals as compared to the other treatments and this results were similar to the work of Barik et al., (2011) reported $\mathrm{N}$ (0.51 and 1.61 per cent), $\mathrm{P}$ (0.19 and 1.02 per cent) and $\mathrm{K}(0.15$ and 0.73 per cent) in the vermicompost from agricultural wastes.

End of the process $\mathrm{pH}$ in the agricultural waste was more in $T_{1}$ (Composting without pretreatment) 7.58 and least in $\mathrm{T}_{4}$ (Vermicomposting with pretreatment) 7.21. $\mathrm{N}$ per cent in the agricultural waste was more in $\mathrm{T}_{3}$ (Vermicomposting without pretreatment) 2.00 per cent and least in $T_{1}$ (Composting without pre treatment) 1.05 per cent (Table 4.6).

The similar kind of results were noticed in the study conducted by Wani et al., (2013) where they have recorded more $\mathrm{N}$ per cent in cow dung (2.03 per cent) observed in the present experiment is similar to the results as 1.95 per cent and 1.91 per cent respectively.

The percentage of highest $\mathrm{N}$ content in $\mathrm{T}_{4}$ (Vermicomposting with pretreatment) (2.41 per cent and 1.80 per cent) from the present work as compared with the results presented by Jeyabal et al., (2001) who studied the composition of nutrients like $\mathrm{N}, \mathrm{P}$ and $\mathrm{K}$ in biogas digested slurry and obtained the $\mathrm{N}$ (1.65 per cent).

The similar kind of results were noticed in the study conducted by Chandrashekara et al., (2011) where, they have recorded more nitrogen content in the compost prepared by using earth worms (1.90 per cent) compared to compost prepared by without inoculum
(1.36 per cent) and also with microbial consortium (1.54 per cent).

$P$ per cent in the agricultural waste was more in $\mathrm{T}_{3}$ (Vermicomposting without pretreatment) 1.52 per cent and least in $T_{2}$ (Composting without pre treatment) 0.38 per cent (Table 4.6).

The similar kind of results were noticed in the study conducted by Singh and Nain (2014) where, they have conducted an experiment microorganisms in the conversion of agricultural wastes to compost and recorded phosphorus content in the compost 0.8 per cent and in vermicompost 0.4 per cent.

$\mathrm{K}$ per cent in the agricultural waste was more in $\mathrm{T}_{3}$ (Vermicomposting without pretreatment) 1.50 per cent and least in $T_{1}$ (Composting without pretreatment) 0.68 per cent (Table 4.6).

The variation in the available potassium content between different treatments at different intervals of composting may be due to variation in chemical characteristics of substrates used and efficiency of organisms involved in degradation as similar kind of results were noticed in the study conducted by Chandrashekara et al., (2011) where, they have recorded more available potassium content in the compost prepared by using earth worms (0.61 per cent) compared to compost prepared by without inoculum (0.42 per cent) and also with microbial consortium ( 0.51 per cent).

Organic carbon per cent in the agricultural waste was more in $\mathrm{T}_{2}$ (Composting with pretreatment) 31.32 per cent and least in $\mathrm{T}_{4}$ (Vermicomposting with pretreatment) 22.52 per cent (Table 4.6). 
Cellulose per cent in the agricultural waste was more in $T_{1}$ (Composting without pretreatment) 16.20 per cent and least in $T_{2}$ (Composting with pretreatment) 15.98 per cent (Table 4.6).

Cellulose per cent in the agricultural waste was similar to the results of Lin et al. (2014) who demonstrated that comparison of solid state anaerobic digestion and composting of yard trimmings with effluent from liquid anaerobic digestion. The cellulose per cent in the substrates were estimated as 19.1, 12.2 , and 23.8 per cent respectively.

The variation in the percentage of cellulose present in the agricultural waste substrate between different treatments at different intervals may be due to variation in chemical characteristics of substrates used and organisms involved in degradation. Similar kind of result was noticed in the study conducted by Chen et al., (2015) where, they have recorded cellulose content was 25.61 per cent.

In conclusion, cellulolytic bacteria had been studied in various soils collected from agricultural college student farm soil, farmer's agriculture field, forest soil and another sample was collected from horse dung FYM manure enriched soil sample nearby college. Samples were also collected from waste receiving dustbin of domestic kitchen wastes sample, municipal solid waste sample, sewage water sample and cow dung sample.

All of these studies were mostly based on the isolation of cellulose degrading bacteria, estimation of population densities using cellulose congo red agar (CCRA) medium plate techniques. By comparing the results of morphological, physiological and biochemical characteristics. The thirty morphologically distinct bacterial isolates which were giving halo zones in CCR agar medium were selected and named as CDS, MSW, DKW, SWS, $\mathrm{C}_{2} \mathrm{~A}, \mathrm{C}_{3} \mathrm{~A}, \mathrm{C}_{3} \mathrm{~B}, \mathrm{C}_{4} \mathrm{~A}$ and $\mathrm{C}_{5} \mathrm{~A}$ identified as cellulose degrading bacteria respectively. Considering the results, it may be concluded that the strains CDS, MSW, DKW, SWS, $\mathrm{C}_{2} \mathrm{~A}, \mathrm{C}_{3} \mathrm{~A}, \mathrm{C}_{3} \mathrm{~B}$, $\mathrm{C}_{4} \mathrm{~A}$ and $\mathrm{C}_{5} \mathrm{~A}$ will be the potential strain for degradation which will be used effectively to prepare compost, vermicompost by pretreatment process. In the present study, number of cellulose degrading bacteria were observed from collected soil samples and waste samples.

Use of these $\mathrm{CDB}$ as bio-inoculants can be incorporated to enhance organic matter decomposition in soil to increase soil fertility and to minimize the fertilizer application. They can also be apply to reduce environmental pollution and promotes sustainable agriculture. From the above findings, it can be concluded that a large number of cellulose degrading microorganisms were found in municipal solid waste, domestic kitchen waste and sewage water sample and soil samples. Biological pretreatment with complex microbial agents proved to be an efficient method to improve biodegradability and enhance the composting, vermicomposting.

A general increase in $\mathrm{pH}$ value recorded during the composting and vermicomposting process, suggests the alkalinization of the agricultural waste because of the release of ammonia from the degradation and mineralization of organic compounds, decrease in $\mathrm{pH}$ between the different intervals may be due to development of anaerobic conditions and accumulation of organic acids in parts of pot. Nutrients like carbon, nitrogen, phosphorus and sulphur are very important for the survival and growth of anaerobic digestion process organism. 
Table.4.1 Isolation of cellulose degrading bacteria from different samples

\begin{tabular}{|c|c|}
\hline Samples & $\left(\times \mathbf{1 0}^{-\mathbf{6}} \mathbf{C F U} \mathbf{~ g}^{-\mathbf{1}}\right)$ \\
\hline CDS & 64 \\
\hline MSW & 97 \\
\hline DKW & 52 \\
\hline SWS & 155 \\
\hline S-1 & 110 \\
\hline S-2 & 145 \\
\hline $\begin{array}{c}\text { C.D. } \\
(\mathbf{P = 0 . 0 5 )}\end{array}$ & $\mathbf{1 . 7 9 9}$ \\
\hline SE(m) & $\mathbf{0 . 5 7 7}$ \\
\hline C.V. & $\mathbf{0 . 9 6 5}$ \\
\hline
\end{tabular}

S- Sample

Table.4.2 Quantitative determination of Cellulase Activity of bacterial isolates

\begin{tabular}{|c|c|c|c|c|c|c|c|}
\hline ZONE-1 & & & & Source & & & \\
\hline S.No & Strain & CDS & MSW & DKW & SWS & Zone $(\mathrm{cm})$ & $\begin{array}{c}\text { Enzyme } \\
\text { activity } \\
\text { (Unit/mg) }\end{array}$ \\
\hline 1 & CDS.10 $0^{-6} \cdot \mathrm{A}$ & + & - & - & - & 0.75 & 0.032 \\
\hline 2 & MSW. $10^{-6} \cdot \mathrm{A}$ & - & + & - & - & 0.35 & 0.020 \\
\hline 3 & MSW. $10^{-7} . \mathrm{B}$ & - & + & - & - & 0.20 & 0.016 \\
\hline 4 & DKW. $10^{-6} \cdot \mathrm{A}$ & - & - & + & - & 0.55 & 0.015 \\
\hline 5 & DKW. $10^{-6} \cdot B$ & - & - & + & - & 0.53 & 0.015 \\
\hline 6 & SWS. $10^{-6} . \mathrm{A}$ & - & - & - & + & 1.25 & 0.136 \\
\hline 7 & SWS.10 ${ }^{-6} \cdot \mathrm{B}$ & - & - & - & + & 1.18 & 0.126 \\
\hline 8 & SWS. $10^{-7} \cdot \mathrm{A}$ & - & - & - & + & 1.13 & 0.124 \\
\hline 9 & CDS.A & - & - & - & - & 0.25 & 0.018 \\
\hline 10 & MSW.A & - & + & - & - & 0.98 & 0.019 \\
\hline 11 & MSW.B & - & + & - & - & 0.75 & 0.020 \\
\hline 12 & DKW.A & - & - & + & - & 0.93 & 0.013 \\
\hline 13 & DKW.B & - & - & + & - & 1.18 & 0.125 \\
\hline 14 & SWS.A & - & - & - & + & 0.98 & 0.024 \\
\hline \multirow[t]{4}{*}{15} & SWS.B & - & - & - & + & 1.38 & 0.149 \\
\hline & C.D. & & & & & 0.058 & 0.005 \\
\hline & SE(m) & & & & & 0.020 & 0.002 \\
\hline & C.V. & & & & & 4.225 & 5.493 \\
\hline
\end{tabular}


Table.4.3 Quantitative determination of Cellulase Activity of bacterial isolates

\begin{tabular}{|c|c|c|c|c|c|c|c|c|}
\hline ZONE-2 & & & & Source & & & & \\
\hline S.No & Strain & Soil sample-1 & Soil sample-2 & MSW & DKW & SWS & Zone (cm) & $\begin{array}{c}\text { Enzyme } \\
\text { activity } \\
\text { (Unit/mg) }\end{array}$ \\
\hline 1 & 1 & + & - & - & - & - & 1.18 & 0.126 \\
\hline 2 & 4 & + & - & - & - & - & 1.38 & 0.148 \\
\hline 3 & 5 & + & - & - & - & - & 0.98 & 0.015 \\
\hline 4 & 6 & + & - & - & - & - & 1.30 & 0.135 \\
\hline 5 & 8 & + & - & - & - & - & 0.95 & 0.014 \\
\hline 6 & 11 & + & - & - & - & - & 1.18 & 0.131 \\
\hline 7 & 13 & + & - & - & - & - & 1.32 & 0.129 \\
\hline 8 & C2A & - & + & - & - & - & 0.93 & 0.032 \\
\hline 9 & C3A & - & + & - & - & - & 0.98 & 0.046 \\
\hline 10 & C3B & - & + & - & - & - & 0.85 & 0.048 \\
\hline 11 & C4A & - & + & - & - & - & 0.95 & 0.023 \\
\hline 12 & C5A & - & + & - & - & - & 0.86 & 0.047 \\
\hline 13 & MSW.10 & - & - & + & - & - & 0.53 & 0.026 \\
\hline 14 & DKW.10 & - & - & - & + & - & 1.25 & 0.136 \\
\hline 15 & SWS.10-4 & - & - & - & - & + & 0.70 & 0.042 \\
\hline & C.D. & & & & & & $\mathbf{0 . 0 5 2}$ & $\mathbf{0 . 0 0 4}$ \\
\hline & SE(m) & & & & & & $\mathbf{0 . 0 1 8}$ & $\mathbf{0 . 0 0 2}$ \\
\hline & C.V. & & & & & & $\mathbf{3 . 0 5 0}$ & $\mathbf{3 . 5 8 0}$ \\
\hline
\end{tabular}

MSW- Municipal solid waste; DKW- Domestic kitchen waste; SWS- Sewage water sample.

Table.4.4 Chemical composition of maize substrate

\begin{tabular}{|c|c|c|c|c|c|c|}
\hline Treatments & $\mathrm{pH}$ & Nitrogen \% & Phosphorus \% & Potassium \% & Organic carbon \% & Cellulose \% \\
\hline $\mathrm{T}_{1}$ & 8.00 & 0.60 & 0.15 & 0.65 & 25.50 & 24.31 \\
\hline $\mathrm{T}_{2}$ & 8.20 & 0.70 & 0.16 & 0.70 & 24.00 & 27.58 \\
\hline $\mathrm{T}_{3}$ & 8.25 & 1.65 & 1.00 & 0.99 & 21.60 & 24.79 \\
\hline $\mathrm{T}_{4}$ & 8.20 & 1.84 & 1.00 & 1.00 & 22.60 & 26.10 \\
\hline
\end{tabular}

Table.4.5 Chemical composition of pretreated substrate

\begin{tabular}{|c|c|c|c|c|c|c|}
\hline Treatments & $\mathrm{pH}$ & Nitrogen \% & Phosphorus \% & Potassium \% & Organic carbon \% & Cellulose \% \\
\hline $\mathrm{T}_{1}$ & 8.18 & 0.70 & 0.17 & 0.72 & 26.70 & 23.02 \\
\hline $\mathrm{T}_{2}$ & 8.26 & 0.90 & 0.19 & 0.78 & 25.00 & 22.98 \\
\hline $\mathrm{T}_{3}$ & 8.33 & 1.91 & 1.06 & 1.01 & 22.00 & 22.05 \\
\hline $\mathrm{T}_{4}$ & 8.28 & 2.41 & 1.10 & 1.05 & 23.50 & 21.10 \\
\hline
\end{tabular}


Table.4.6 Chemical composition during composting and vermicomposting of pretreated agricultural waste (maize straw)

\begin{tabular}{|c|c|c|c|c|c|c|}
\hline Treatments & $\mathrm{pH}$ & Nitrogen $\%$ & Phosphorus $\%$ & Potassium \% & Organic carbon \% & Cellulose $\%$ \\
\hline $\mathrm{T}_{1}$ & 7.58 & 1.05 & 0.40 & 0.68 & 26.50 & 16.20 \\
\hline $\mathrm{T}_{2}$ & 7.45 & 1.14 & 0.38 & 0.73 & 31.32 & 15.98 \\
\hline $\mathrm{T}_{3}$ & 7.30 & 2.00 & 1.52 & 1.50 & 24.60 & 17.26 \\
\hline $\mathrm{T}_{4}$ & 7.21 & 1.95 & 1.50 & 1.25 & 22.52 & 18.02 \\
\hline
\end{tabular}

Fig.4.1 Isolation of cellulose degrading bacteria from different samples

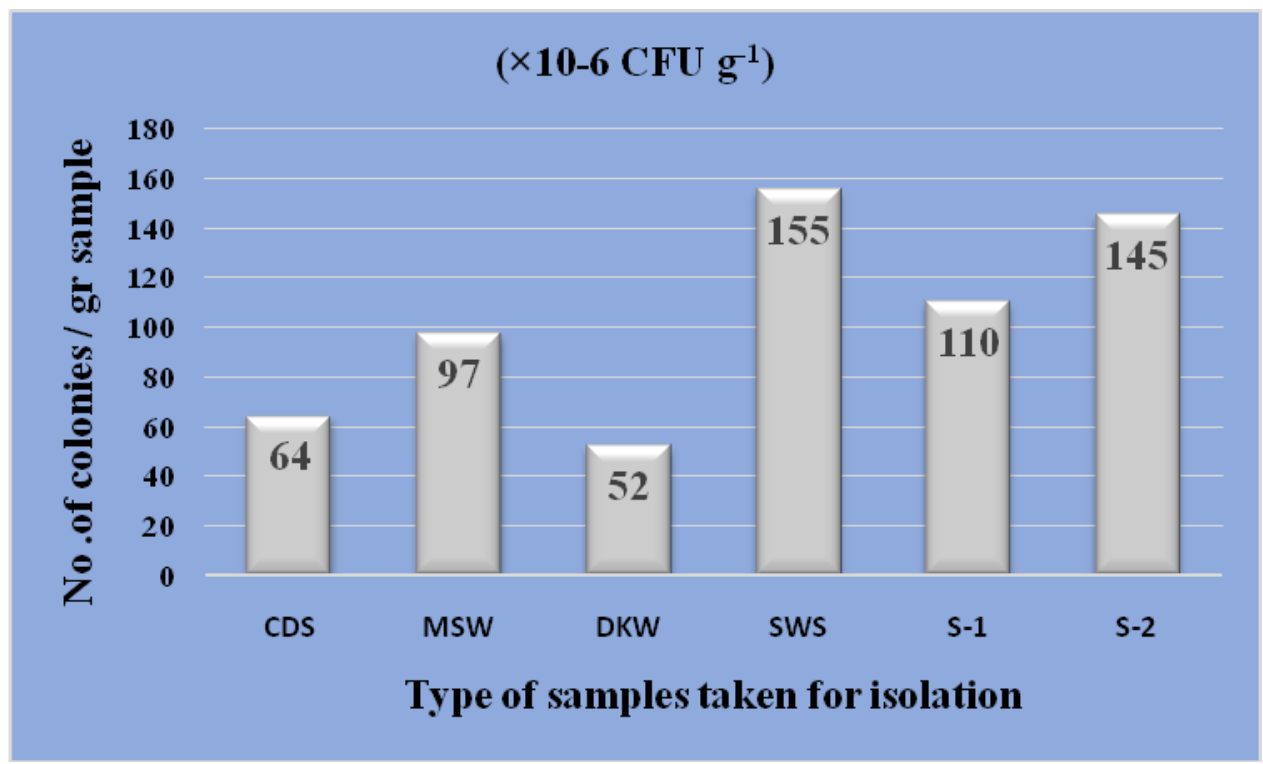

Fig.4.2.1 Quantitative determination of Cellulase Activity of bacterial isolates

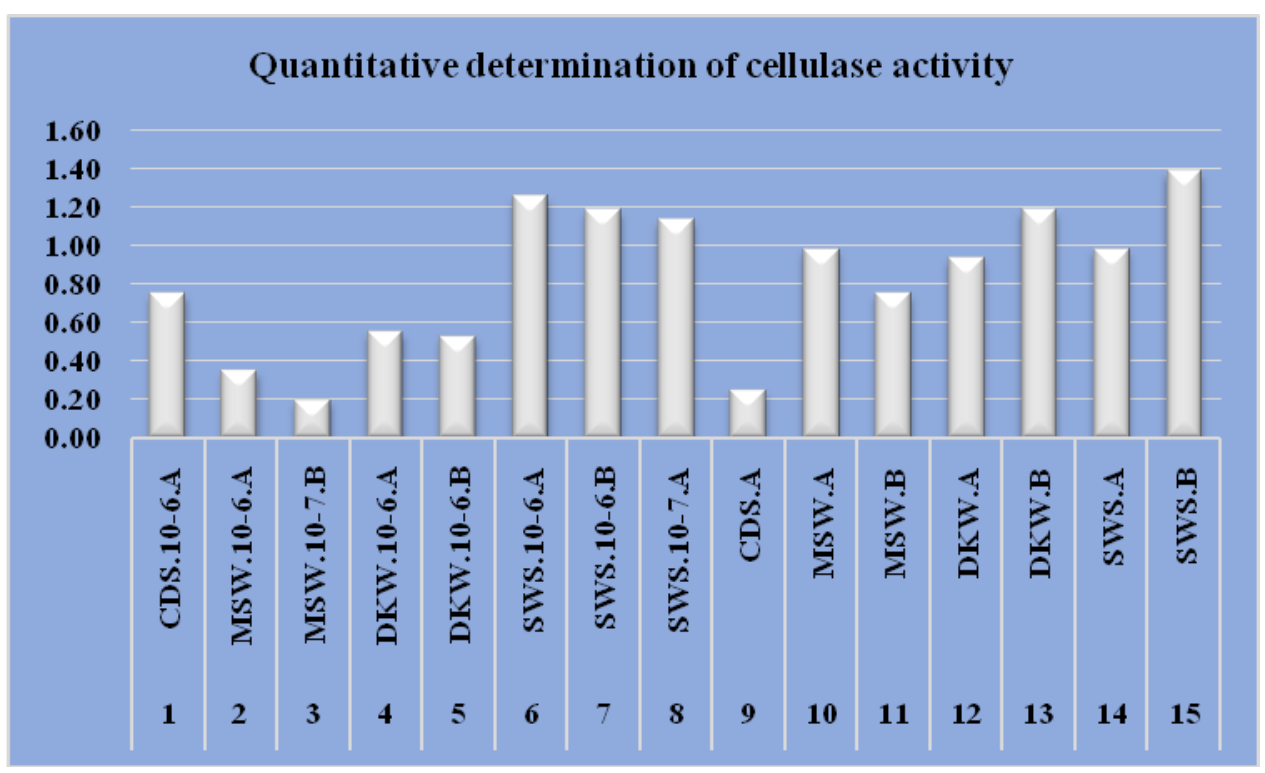


Fig.4.2.2 Qualitative determination of Cellulase Activity of bacterial isolates

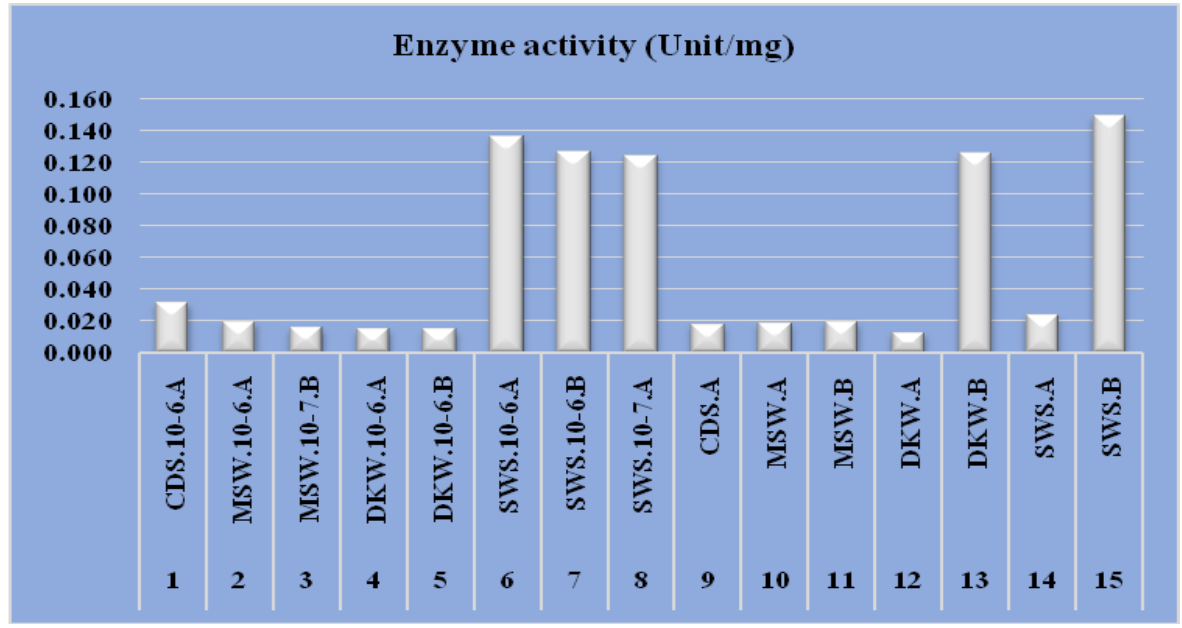

Fig.4.3.1 Quantitative determination of Cellulase Activity of bacterial isolates

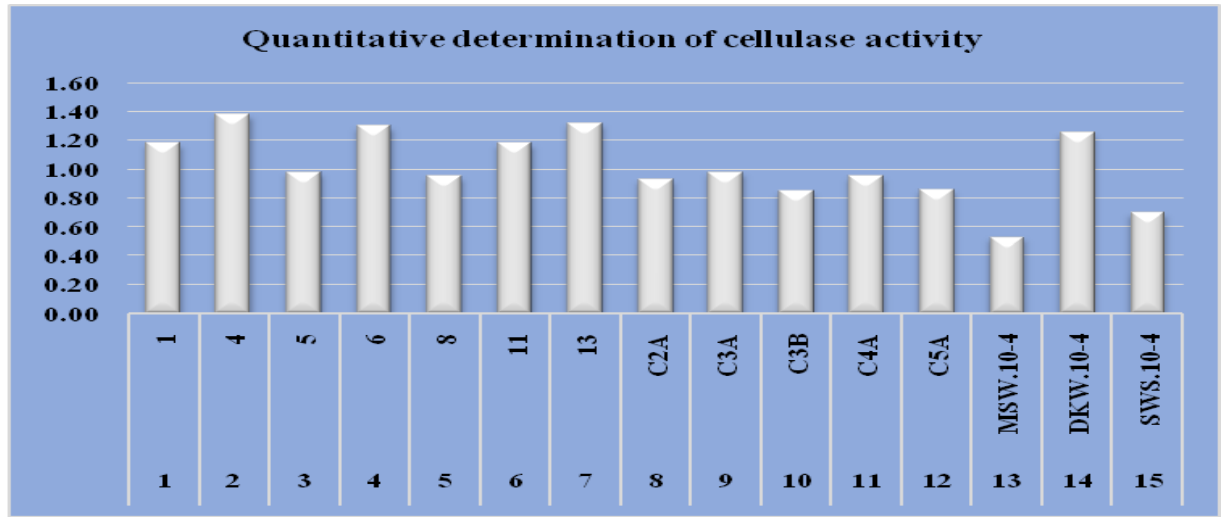

Fig.4.3.2 Qualitative determination of Cellulase Activity of bacterial isolates

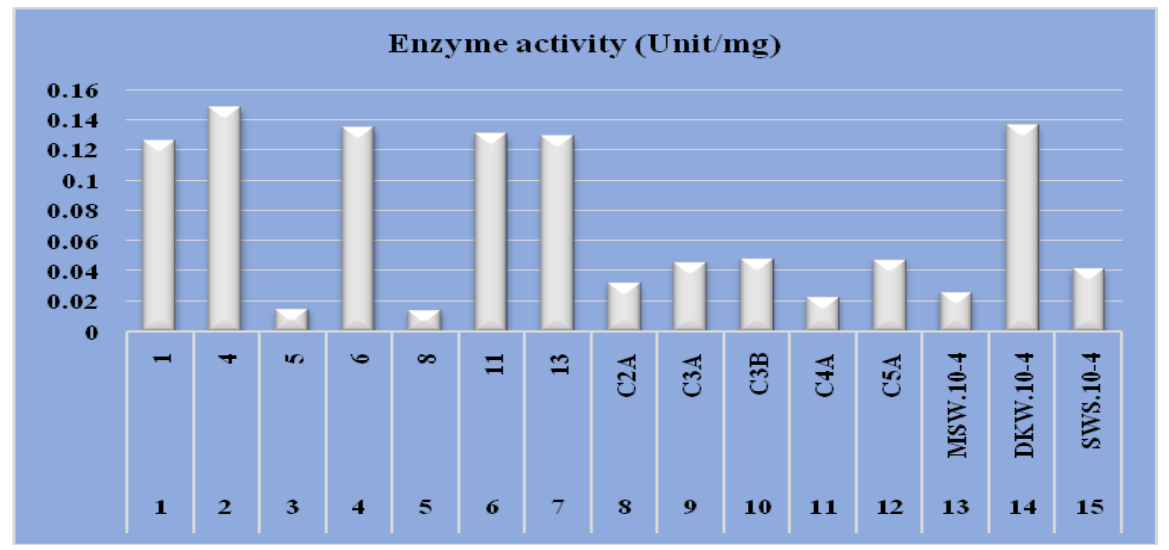

The ideal carbon to nitrogen $(\mathrm{C}: \mathrm{N})$ ratio for anaerobic digestion ranges from approximately $20: 1$ to $30: 1$. A significant decrease of nutrients percentage of the agricultural waste substrate and the total $\mathrm{N}$ content changed slightly with the 
vermicomposting time. This may be due to existance of labile organic compounds, such as simple carbohydrates, fats and amino acids in the food waste that are degraded quickly in the first stage of vermicomposting.Decomposition of organic substrates and reduction of phytotoxic compounds resulting from vermicompost ageing. Vermicomposts produced by earthworm species showed higher contents of nutrients compared to that of the sole compost as well as substrates the agricultural waste (maize straw). Moreover, the vermicompost and compost of agricultural waste waste possessed higher nutrient contents. Earthworms act in the soil as aerators, grinders, crushers, chemical degraders and biological stimulators. They secrete enzymes, proteases, lipases, amylases, cellulases and chitinases which bring about rapid biochemical conversion of the cellulosic and the proteinaceous materials in the variety of organic wastes which originate from homes, gardens, dairies and farms. The process is odour free because earthworms release coelomic fluids in the decaying waste biomass which has anti-bacterial properties which kills pathogens. Organic substrates degraded at a lower rate and nutrient content decreased slightly at the end of the process. This can be due to existing of resistant organic substrates, such as cellulose, hemicellulose and lignin in the process that are degraded partially. Composting or vermicomposting involves a partial mineralization of the organic substrate, leading to carbon losses throughout the process. A significant reduction of this nutrient status during the composting and vermicomposting process was mainly due to the depletion of easily degradable carbon compounds and $\mathrm{C}$ losses as $\mathrm{CO}_{2}$.

However, all the combinations were also proved to be better for their manurial value.
Though $\mathrm{N}$ per cent, $\mathrm{P}$ per cent and organic carbon per cent increased in all the treatments of agricultural waste. Reduction in $\mathrm{K}$ per cent was observed but less reduction was observed in agricultural waste. Hence it can be concluded that agricultural waste was comparatively better in $\mathrm{N}, \mathrm{P}, \mathrm{K}$ and organic carbon per cent composition while agricultural waste were also good and can be used as compost and vermicompost making and also useful for the production of biogas.

\section{References}

Andro, T., Chambost, J.P., Kotoujansky, A., Cattano, J and Barras, F. 1984. Mutants of erwinia chrysanthemi defective in secretion of pectinase and cellulase. $J$. Bacteriol., 160:1199-1203.

Bailey, M.J., Biely, P and Poutanen, K. 1992. Inter-laboratory testing of methods for assay of xylanase activity. $J$. Biotechnol., 23: 257-270.

Barik, T., Gulati, J.M.L., Garnayak, L.M and Bastia, D.K. 2011. Production of vermin compost from agricultural wastes- a review. Agri. Res. Communication Centre, 31(3): 172 -183.

Carey, D.E, Yang, Y., McNamara, P.J and Mayer, B.K. 2016. Recovery of agricultural nutrients from bio refineries. Biores. Technol., 215: 186-198.

Chandrashekara, U.M., Balasundaran, M., Baiji, E.C and Nishad, V.M. 2011. Combined effect of microbes and earthworms on compost and its influence on crop growth and yield. $J$. Soil Biol. Ecol., 31(1\&2): 183-194.

Chen, Y., Yufen, Z., Quanguo, Z., Lixin, X., Ran, L., Xiaopei, L., Xin, $Z$ and Jin, T.2015. Earthworms modify microbial community structure and accelerate maize stover decomposition during vermin composting. Environ. Sci. Poll. Res., 22:17161-17170.

Cowan, S.T and Steel, K.J. 1993. Manual for the identification of medical bacteria $3^{\text {rd }}$ 
edition; Cambridge University press, USA. 150-152.

Cullimore, D.R. Practical Atlas for Bacterial Identification. 2000. Lewis Publishers, Boca Raton, London, New York. 209.

Hatami, S., Alikhani, H.A., Besharati, H., Salehrastin, N., Afrousheh, $\mathrm{M}$ and Yazdani, J. 2008. Investigation on aerobic cellulolytic bacteria in some of north forest and farming Soils. American-Eurasian J. Agric. \& Environ. Sci., 3 (5): 713-716.

Jeyabal, A and Kuppuswamy, G. 2011. Recycling of organic wastes for the production of vermicompost and its response in rice-legume cropping system and soil fertility. European J Agronomy, 15: 153-170.

Kumar, R., Verma, D., Bhanu, L., Singh, Umesh, K and Shweta. 2010. Composting of sugar-cane waste byproducts through treatment with microorganisms and subsequent vermicomposting. Biores. Technol., 101 (17): 6707-6711.

Lee, S.M and Koo, Y.M. 2008. Pilot-scale production of cellulose using Trichoderma reesei Rut C-30 in fedbatchmode. J. Microbiol. Biotechnol., 11: 229-233.

Lemee, L., Kpogbemabou, D., Pinard, L., Beauchet, R and Laduranty, J. 2012. Biological pretreatment for production of lignocellulosic biofuel. Biores. Technol., 117: 234-241.

Lin, L., Liangcheng, Y., Fuqing, Xu., Frederick, C., Michel and Yebo, Li. 2014.Comparison of solid-state anaerobic digestion and composting of yard trimmings with effluent from liquid anaerobic digestion. Bioresource Technol., 169: 439-446.

Miller, G.L. 1959. Use of dinitrosalicylic acid reagent for determination of reducing sugar. Anal Chem. 31(4):426-428.

Shoham, Y., Lamed, R and Bayer, E.A. The cellulosome concept as an efficient microbial strategy for the degradation of insoluble polysaccharides. Trends Microbiol., 7(7):275-281.

Singh, S and Nain, L. 2014. Microorganisms in the conversion of agricultural wastes to compost. Proceedings of the Indian National Science Academy, 80 (2): 473481.

Thambirajah, J.J., Zulkafli, M.D and Hashim, M.A. 2005. Microbiological and biochemical changes during thecomposting of oil palm empty fruit bunches. Effect of nitrogen supplementation on the substrate. Biores. technol., 52: 133-134.

Updegraff, D.M. 1969. Semimicro determination of cellulose in biological materials. Anal. Biochem., 32: 420-424.

Wani, K.A., Mamta, and Rao, R.J. 2013. Bioconversion of garden waste, kitchen waste and cow dung into value-added products using earthworm Eisenia fetida. Saudi J. Biol. Sci., 20: 149-154.

Yin, L.J., Huang, P.S and Lin, H.H. Isolation of cellulose producing bacteria and characterization of the cellulase from the isolated bacterium cellulomonas sp. $J$. Agric. Food Chem., 58: 9833-9837.

\section{How to cite this article:}

Prasanna Kumar, B., S. Triveni, R. Subhash Reddy and Vijaya Gopal, A. 2016. Effect of Cellulolytic Pretreatment of Agricultural Waste on Organic Matter Degradation. Int.J.Curr.Microbiol.App.Sci. 5(12): 23-35. doi: http://dx.doi.org/10.20546/ijcmas.2016.512.004 